\title{
C 型肝炎治療薬の偽造品に関する成分分析
}

\author{
内山奈穂子, * 鎌倉浩之, 政田さやか, 辻本 恭, 細江潤子, \\ 徳本廣子，丸山卓郎，合田幸広，袴塚高志
}

\section{Chemical Analysis of Counterfeit Hepatitis C Drug Found in Japan}

\author{
Nahoko Uchiyama, ${ }^{*}$ Hiroyuki Kamakura, Sayaka Masada, Takashi Tsujimoto, Junko Hosoe, \\ Hiroko Tokumoto, Takuro Maruyama, Yukihiro Goda, and Takashi Hakamatsuka \\ National Institute of Health Sciences (NIHS); 1-18-1 Kamiyoga, Setagaya-ku, Tokyo 158-8501, Japan.
}

(Received June 5, 2017; Accepted July 4, 2017; Advance publication released online July 19, 2017)

In January 2017, counterfeits of the hepatitis C drug 'HARVONI ${ }^{\circledR}$ Combination Tablets' (HARVONI ${ }^{\circledR}$ ) were found at a pharmacy chain through unlicensed suppliers in Japan. A total of five lots of counterfeit HARVONI ${ }^{\circledR}$ (samples 1-5) bottles were found, and the ingredients of the bottles were all in tablet form. Among them, two differently shaped tablets were present in two of the bottles (categorized as samples 2A, 2B, 4A, and 4B). We analyzed the total of seven samples by high-resolution LC-MS, GC-MS and NMR. In samples 2A, 3 and 4B, sofosbuvir, the active component of another hepatitis C drug, SOVALDI ${ }^{\circledR}$ Tablets $400 \mathrm{mg}$ (SOVALDI ${ }^{\circledR}$ ), was detected. In sample 4A, sofosbuvir and ledipasvir, the active components of $\mathrm{HARVONI}^{\circledR}$, were found. A direct comparison of the four samples and genuine products showed that three samples $(2 \mathrm{~A}, 3,4 \mathrm{~B})$ are apparently SOVALDI ${ }^{\circledR}$ and that sample 2A is HARVONI ${ }^{\circledR}$. In samples 1 and 5 , several vitamins but none of the active compounds usually found in HARVONI ${ }^{\circledR}$ (i.e., sofosbuvir and ledipasvir) were detected. Our additional investigation indicates that these two samples are likely to be a commercial vitamin supplement distributed in Japan. Sample 2B, looked entirely different from HARVONI ${ }^{\circledR}$ and contained several herbal constitutents (such as ephedrine and glycyrrhizin) that are used in Japanese Kampo formulations. A further analysis indicated that sample $2 \mathrm{~B}$ is likely to be a Kampo extract tablet of Shoseiryuto which is distributed in Japan. Considering this case, it is important to be vigilant to prevent a recurrence of distribution of counterfeit drugs.

Key words_— counterfeit drug; hepatitis C drug; GC-MS; LC-MS; NMR

$$
\text { 緒 言 }
$$

日本を含めて世界的に偽造薬の流通は問題となつ ているが，日本においてこれまでに報告されている 医薬品の偽造品は, 強壮作用や瘦身作用を暗に標榜 して無承認無許可医薬品として通常の医薬品ルート を通さず販売されているものが多い. 特にシルデナ フィル関連の強壮薬の偽造品はインターネットを介 した個人輸入などにより国内に流通している例が多 く報告されている. ${ }^{1-7)}$ 今回新たな種類の偽造薬と して, C 型肝炎治療薬「ハーボニー『配合錠」の偽 造品が流通する事案が平成 29 年 1 月に発生し

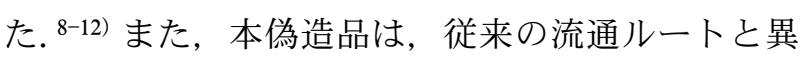
なり, 医薬品の卸売販売業者及び薬局を通じて患者

国立医薬品食品衛生研究所

*e-mail: nuchiyama@ nihs.go.jp
に渡っており，この点でも注目するべき新たな事案 であった。

$\mathrm{C}$ 型肝炎治療薬「ハーボニー『配合錠」は，2015 年 9 月より国内で販売が開始された医薬品であり, その有効成分としてソホスブビル及びレジパスビル の 2 化合物を含有する. また，ソホスブビルを有効 成分とした C 型肝炎治療薬「ソバルディ ${ }^{\circledR}$ 錠 400 $\mathrm{mg} 」$ は，「ハーボニー『配合錠」販売以前の 2015 年 5 月に国内販売が開始されている。 その製品形態 は，ブリスター(press through pack; PTP) 包装シー トなどのように直接薬の形態が分かるものではな く, ボトル包装であり, 直接ボトルの中身が確認で きない形態であった。また，「ハーボニー ${ }^{\circledR}$ 配合錠」 は非常に高額な医薬品であるが，その偽造品は，既 に 2016 年 3 月にイスラエルで発見されている. ${ }^{13)}$ 偽造品のボトルは，インドで製造されたプラスチッ クボトルがスイスの商社を経由して輸入されたもの 
Table 1. Samples Used in This Study

\begin{tabular}{l|l|c|c}
\hline \hline \multicolumn{1}{c|}{ Sample } & Appearance form/Form and color after crushing & Size: Length $\times$ Width $\times$ Thickness $(\mathrm{mm})$ & Weight $(\mathrm{mg})$ \\
\hline Sample 1 & Yellow oblong tablet/Yellow powder & $8.9 \times 20.4 \times 7.7$ & 1488 \\
\hline Sample 2A & Yellow oblong tablet/White powder & $9.1 \times 20.2 \times 7.0$ & 1232 \\
\hline Sample 2B & $\begin{array}{l}\text { Violet round tablet/Brown powder } \\
\text { (Characteristic odor like crude drugs or herbs) }\end{array}$ & $9.1($ i.d. $) \times 5.3$ & 337 \\
\hline Sample 3 & Yellow oblong tablet/White powder & $9.1 \times 20.3 \times 7.1$ & 1236 \\
\hline Sample 4A & Orange diamond tablet/White powder & $10.4 \times 19.8 \times 6.9$ & 1044 \\
\hline Sample 4B & Yellow oblong tablet/White powder & $9.2 \times 20.3 \times 7.2$ & 1272 \\
\hline Sample 5 & Yellow oblong tablet/Yellow powder & $8.9 \times 20.4 \times 7.7$ & 1534 \\
\hline
\end{tabular}

であり，「ハーボニー ${ }^{\circledR}$ 配合錠」の正規品は橙色ひし 形の錠剂であるが，偽造品は白色の錠剤を含んでい た. ${ }^{13)}$ 一方, 今回本事案で発見された偽造品のボ卜 ルは，奈良県内のチェーン薬局から調剂された上 で，患者に渡っていた。厚生労働省の調査では, チェーン薬局の経営会社が，製造販売業者が指定す る卸売販売業者から仕入れる「正規ルート」とは異 なる流通経路で本剂を入手していたことが判明して いる. ${ }^{8-12)}$ 最終的に確認された偽造品のボトルは 5 種類の製品ロットがあり，合計 15 本であった。こ のうち薬局で 5 本が発見され, 卸売販売業者で 10 本が発見された. ${ }^{8-12)}$

本研究では，本事案で発見されたこれら偽造品の 実態把握のため, GC-MS, 高分解能 LC-MS 及び NMR による分析を行ったので報告する. ${ }^{12)}$

\section{実 験 方 法}

1. 試料及び調製法奈良県内の薬局で見つ かったハーボニー典合錠の偽造品ロット別の 5 製 品（すべて錠剤）を入手した。なお，同一のボトル に 2 種類の錠剂が認められた 2 製品については，各 錠剂を $\mathrm{A} ， \mathrm{~B}$ とし，計 7 検体を分析した（Table 1). 各検体の外観及び粉砕時の色・形状等は Table 1 に示した。 また, 各検体の写真は, 厚生労働省の 報道発表資料に掲載されている。 ${ }^{9-12)}$ 各検体を粉砕 した後, 粉末 $50 \mathrm{mg}$ にメタノール $2 \mathrm{~mL}$ を加えて 20 分間超音波処理し, フィルターろ過したものを 試料原液 $(25 \mathrm{mg} / \mathrm{mL})$ とした。試料原液は適宜希 釈し試料溶液とした。

2. 試薬＼cjkstart対照品として，ギリアド社より提供 された正規品（ハーボニー『配合錠，ソバルディ錠
$400 \mathrm{mg}$ ）及びその有効成分であるソホスブビル (Sofosbuvir)，レジパスビル（Ledipasvir）の標品 を使用した。 それぞれの形態内訳は Table 2 に示し た通りである。また，ビタミン類及び天然化合物の 標準物質は，国立衛研所蔵のものを用いた。

\section{3. 分析条件}

3-1. GC-MS 装置：GCMS-TQ8040 及び GC-2010（島津製作所製，京都），カラム：DB-5 (30 m $\times 0.25 \mathrm{~mm}$ i.d., 膜厚 $0.25 \mu \mathrm{m}$, Agilent 社製, Santa Clara), キャリアーガス : ヘリウム, $1 \mathrm{~mL} /$ $\min$, 注入法 : スプリット $(10 / 1)$, 注入量 : $1 \mu \mathrm{L}$, 気化室温度 : $200^{\circ} \mathrm{C}$, インターフェイス温度 : $250^{\circ} \mathrm{C}$, カラム温度 : $60^{\circ} \mathrm{C}(1 \mathrm{~min}$ hold $)-10^{\circ} \mathrm{C} / \mathrm{min}-320^{\circ} \mathrm{C}$ (15 min hold), イオン化法：電子イオン (EI) 法, 質量範囲 : $m / z$ 45-1000.

3-2. 高分解能 LC-MS 装置 : UltiMate 3000 RS LC system 及び Q Exactive Quadrupole-Orbitrap ハイブリッド型質量分析計（Thermo Fisher Scientific 社製，Waltham)，カラム：ACQUITY UPLC HSS T3 column $(100 \times 2.1 \mathrm{~mm}$ ，粒子系 $1.8 \mu \mathrm{m}$, Waters 社製，Milford)，移動相：A） $0.1 \%$ ギ酸水 溶液，B） $0.1 \%$ ギ酸アセトニトリル.

〈グラジエント条件〉（1）ハーボニー配合錠関係 化合物，生薬関係成分 : $95 \% \mathrm{~A} / 5 \% \mathrm{~B}-60 \% \mathrm{~A} / 40 \% \mathrm{~B}$ (0-10 min) $-40 \% \mathrm{~A} / 60 \% \mathrm{~B}(10-12 \mathrm{~min})-10 \% \mathrm{~A} / 90$ \% B (12-16 min, 11 min hold). (2) ビタミン類関係 化合物： $99 \% \mathrm{~A} / 1 \% \mathrm{~B} \quad(0-5 \mathrm{~min}$ hold $)-80 \% \mathrm{~A} / 20 \%$ B (5-15 min ) $-5 \%$ A $/ 95 \%$ B (15-16 min, $11 \min$ hold).

流速: $0.4 \mathrm{~mL} / \mathrm{min}$, 力ラム温度 : $40^{\circ} \mathrm{C}$, 注入 量: $2 \mu \mathrm{L}$, 検出：質量分析装置及びフォトダイオー 
Table 2. Comparison Products and Standard Materials

\begin{tabular}{|c|c|c|c|}
\hline Comparison subjects & $\begin{array}{l}\text { Appearance form/ } \\
\text { Form and color after crushing }\end{array}$ & $\begin{array}{l}\text { Size: Length } \times \text { Width } \\
\times \text { Thickness }(\mathrm{mm})\end{array}$ & $\underset{(\mathrm{mg})}{\text { Weight }}$ \\
\hline HARVONI ${ }^{\circledR}$ Combination Tablets & Orange diamond tablet/White powder & $10.4 \times 19.7 \times 6.8$ & 1036 \\
\hline SOVALDI $^{\circledR}$ Tablets $400 \mathrm{mg}$ & Yellow oblong tablet/White powder & $9.2 \times 20.2 \times 7.2$ & 1252 \\
\hline Sofosbuvir (standard material) & White powder & - & - \\
\hline Ledipasvir tartrate (standard material) & White powder & - & - \\
\hline Commercial supplement A & Yellow oblong tablet/Yellow powder & $8.9 \times 20.4 \times 7.7$ & 1527 \\
\hline Kampo extract product of Shoseiryuto & $\begin{array}{l}\text { Violet round tablet/Brown powder (Charac- } \\
\text { teristic odor like crude drugs or herbs) }\end{array}$ & 9.1 (i.d.) $\times 5.3$ & 332 \\
\hline Kampo extract product of Kakkonto & $\begin{array}{l}\text { Violet round tablet/Brown powder (Charac- } \\
\text { teristic odor like crude drugs or herbs) }\end{array}$ & 9.0 (i.d.) $\times 5.2$ & 312 \\
\hline
\end{tabular}

ドアレイ [Photodiode Array（PDA）]検出器（測 定波長：190-600 nm).

＜質量分析条件＞イオン化：エレクトロスプ レーイオン化（ESI） 法，ポジティブ [Positive (Pos) ] 及びネガティブ [Negative (Neg)] モード, キャピラリー温度 : $320^{\circ} \mathrm{C}$, 気化温度 $: 300^{\circ} \mathrm{C}$, 脱溶 媒ガス：ヘリウム，スプレー電圧 $: 4.0 \mathrm{KV}$ ，コー ン電圧 : $35.0 \mathrm{~V}$ ，ノーマライズコリジョンエネル ギー : $30.0 \mathrm{~V}$, 質量範囲 $: m / z 100-1500$. キャリブ レーション: LTQ Velos ESI ポジティブイオン キャリブレーション溶液及び ESI ネガティブイオ ンキャリブレーション溶液 [いずれも Pierce 社 （Thermo Fisher Scientific 社）製］を使用した。

3-3. NMR 装置：ECA800，CH-cold probe 付属(いずれも JEOL 社製, 東京)。測定核種 : ${ }^{1} \mathrm{H}$, ${ }^{13} \mathrm{C}$, 測定溶媒 : methanol- $d_{4}[99.96 \%$, ISOTEC 社（Sigma-Aldrich 社，St. Louis）製].内部基準 物質 : Tetramethylsilane (TMS).

\section{結果}

各検体の外観及び形状等から，ハーボニー『配合 錠あるいはソバルディ ${ }^{\circledR}$ 錠 $400 \mathrm{mg}$ と推測される検 体 (検体 $2 \mathrm{~A}, 3,4 \mathrm{~A}, 4 \mathrm{~B}$ の錠剤)，及びハーボニー ${ }^{\circledR}$ 配合錠あるいはソバルディ錠 $400 \mathrm{mg}$ とは異なる 検体（検体 1,2B 及び 5）があった（Tables 1 and

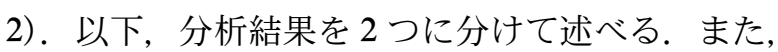
検出化合物の構造式を Fig. 1 に示す.

1. ハーボニー配合錠あるいはソバルディ®錠 $400 \mathrm{mg}$ と推測される検体 (検体 $2 \mathrm{~A}, 3,4 \mathrm{~A}, 4 \mathrm{~B}$ の錠剂)

1-1. 検体 2A, 3 及び 4B 検体 $2 \mathrm{~A}, 3,4 \mathrm{~B}$ は黄
色の錠剂であり，粉砕時の色は白色の粉末であつ た.また，これら 3 検体の外観や粉砕時の形状など は，正規品であるソバルディ錠 $400 \mathrm{mg}$ に類似し ていた (Tables 1 and 2). 各検体の LC-PDA-MS 分析を行った結果, 上記 3 検体から, ソバルディ ${ }^{\circledR}$ 錠 $400 \mathrm{mg}$ の有効成分であるソホスブビル（Sofosbuvir） [Fig. 1 (a)] が検出され，その total ion chromatograms (TIC) クロマトグラム (Pos)，マ ススペクトル及び UV スペクトルは，ソバルディ ${ }^{\circledR}$ 錠 $400 \mathrm{mg}$ と類似していた[Figs. 2(a)-(d)].また, TIC クロマトグラム（Neg）及び LC-PDA クロマ トグラムも同様に類似していた (data not shown). なお, ソホスブビルは, 標品との直接比較により同 定した。 また，GC-MS 分析では，分解物らしきも のは検出されたものの，化合物の同定には至らな かった（data not shown）。そこで， ${ }^{1} \mathrm{H}$-及び ${ }^{13} \mathrm{C}$ NMR を測定し，検体 2A， 3，4B [Supplementary material Figs. S-1 (b)-(d)］と，ソバルディ ${ }^{\circledR}$ 錠 400 mg [Supplementary material Fig. S-1 (a)], ソホス ブビル標準品とのスペクトルの一致をもって化合物 を同定した．さらに，検体 $2 \mathrm{~A}, 3,4 \mathrm{~B}$ の錠剤につい ては，LC-UVによる簡易的な定量を行った結果， ソホスブビルがギリアド社製の正規品（ソバル ディ®錠 $400 \mathrm{mg}$ ） と同程度に含有されていること が判明した (data not shown).

添加物，不純物プロファイル，製剂学的特性等の 同等性は検証していないため，確定的な結論を出す ことは難しいが，以上の分析結果及び各検体の外 観, サイズ，粉末の性状等から判断する限り，検体 2A，3，4B の錠剤はソバルディ錠 $400 \mathrm{mg}$ である可 
a)<smiles>CC(C)OC(=O)C(C)NP(=O)(OC[C@H]1O[C@@H](n2ccc(=O)[nH]c2=O)C(O)C1(F)F)Oc1ccccc1</smiles>

Sofosbuvir

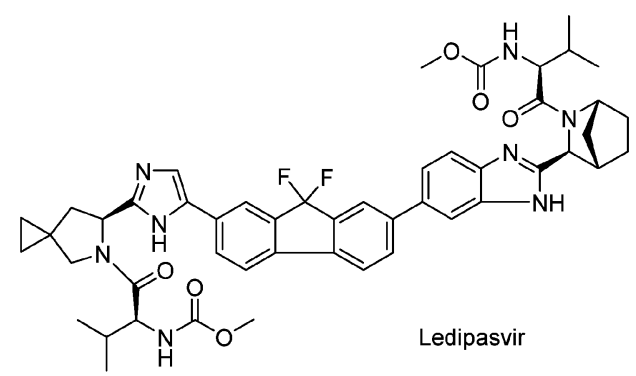

b)<smiles>Cc1ncc(C[n+]2csc(CCO)c2C)c(N)n1</smiles>

c)<smiles>CC(C)C(O)c1ccccc1</smiles>

Ephedrine<smiles>CNC(C)C(O)c1ccccc1</smiles>

$$
\text { Pseudoephedrine }
$$

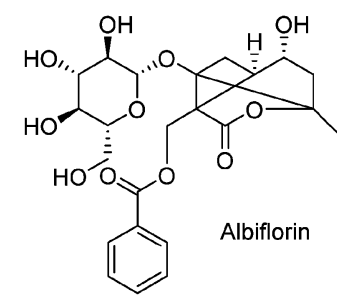

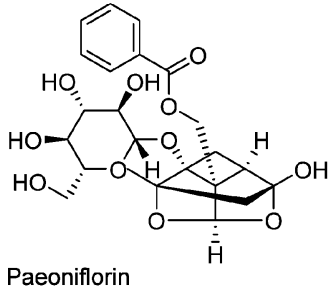<smiles>O=C(O)/C=C/c1ccccc1</smiles>
Cinnamic acid<smiles>COc1cc2c(c(OC)c1OC)-c1c(cc(OC)c(OC)c1OC)CC(C)(O)CC2</smiles>

Schizandrin *<smiles>COc1cc2c(c(OC)c1OC)-c1c(cc3c(c1OC)OCO3)C[C@@H](C)[C@](C)(O)C2</smiles>

HO<smiles>C=C1C[C@H](c2ccc(OC3O[C@H](CO)[C@@H](O)C(O)C3O)cc2)Oc2cc(O)ccc21</smiles>

[6]-Shogaol (*)<smiles>CCCCC[C@H](O)CC(=O)CCc1ccc(O)c(OC)c1</smiles>

(+)-[6]-Gingerol

Asarinin *

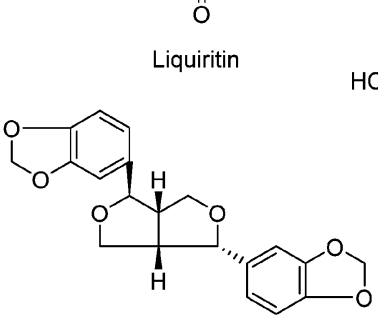

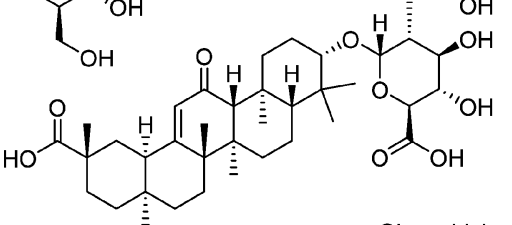

Glycyrrhizin

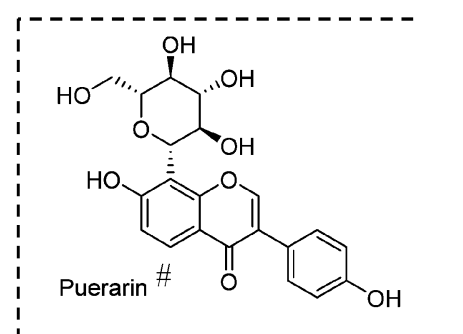

Fig. 1. Structures of Detected Compounds

*Detected in Shoseiryuto not Kakkonto, "detected in Kakkonto not Shoseiryuto. 
TIC (+)

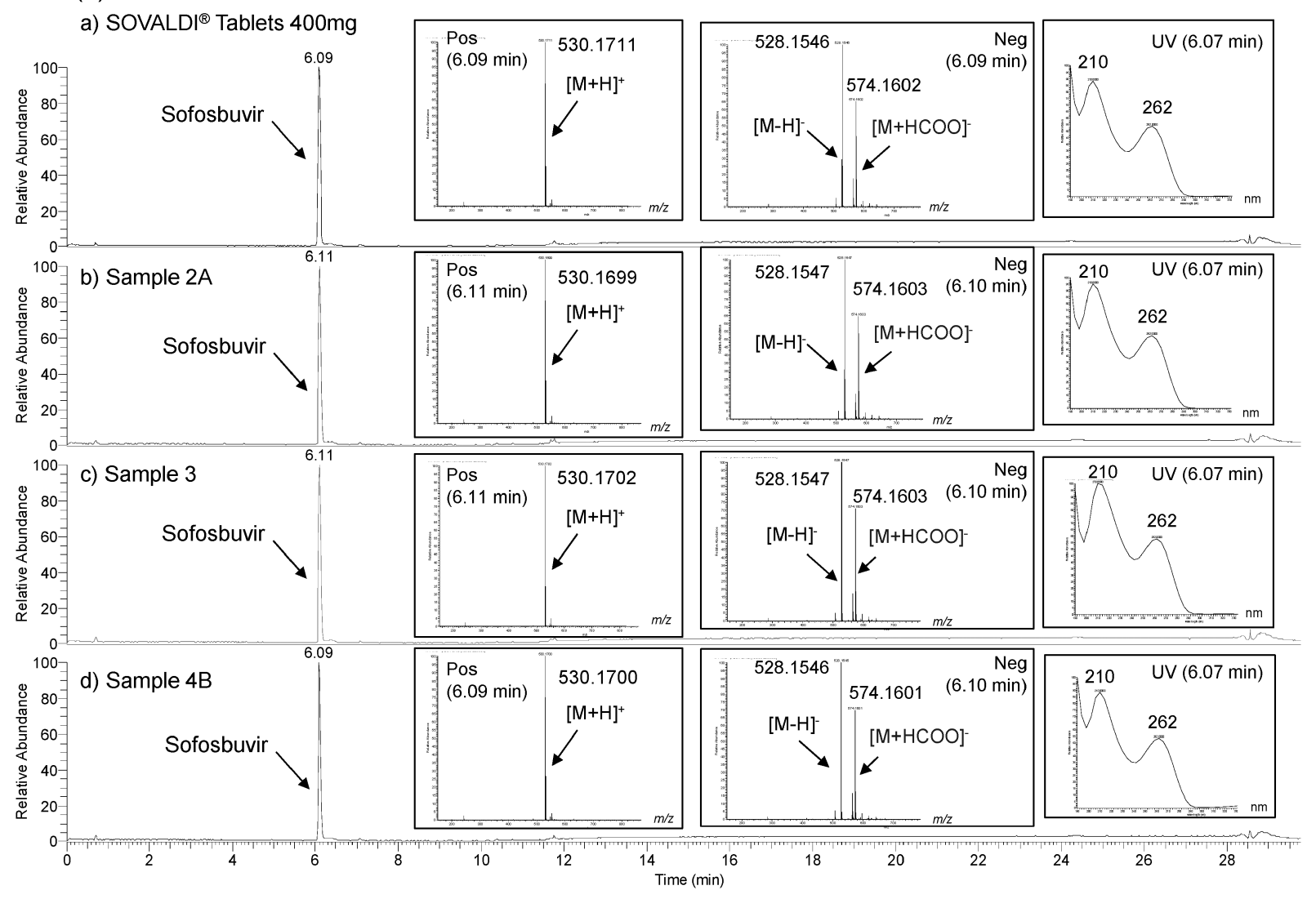

Fig. 2. LC-PDA-MS Analysis of SOVALDI ${ }^{\circledR}$ Tablets $400 \mathrm{mg}$, Samples $2 \mathrm{~A}, 3$ and $4 \mathrm{~B}$ (Pos/Neg/UV)

能性が極めて高いものと推定された。

1-2. 検体 4A 検体 4A は橙色の錠剂であり, 粉砕時の色は白色の粉末であった。 また，本検体の 外観や粉砕時の形状などは，正規品であるハーボ ニー『配合錠に類似していた（Tables 1 and 2)。 LC-PDA-MS 分析を行った結果，本検体から， ハーボニー配合錠の有効成分であるソホスブビル （Sofosbuvir）及びレジパスビル (Ledipasvir) の 2 成分が検出され $[$ Fig. 1(a)], 本検体の TIC クロマ トグラム（Pos/Neg）及び LC-PDA クロマトグラ ムはハーボニー『配合錠と類似していた [Figs. 3(a)(c) ]. また, 本検体中の 2 成分：ソホスブビル及び レジパスビルのマススペクトル（Pos/Neg）及び UV スペクトルについても，ハーボニー®配合錠の ものとよく一致した [Figs. 3(a)-(c)]. なお，ソホ スブビル及びレジパスビルは, 各標品との直接比較 により同定した (data not shown). GC-MS 分析で は，分解物らしきものは検出されたものの，化合物 の同定には至らなかった (data not shown)。 そこ で， ${ }^{1} \mathrm{H}$-及び ${ }^{13} \mathrm{C}-\mathrm{NMR}$ を測定し，検体 4A と，八ー
ボニー『配合錠，ソホスブビル及びレジパスビル標 準品とのスペクトルの一致をもって両化合物を同定 した (data not shown)。さらに，検体 4A の錠剤 については，LC-UVによる簡易的な定量を行った 結果，ソホスブビルがギリアド社製の正規品（ハー ボニー配合錠）と同程度に含有されていることが 判明した (data not shown).

本検体についても, 添加物, 不純物プロファイ ル，製剤学的特性等の同等性は検証していないた め, 確定的な結論を出すことは難しいが，以上の分 析結果及び各検体の外観，サイズ，粉末の性状等か ら判断する限り，検体 4A の錠剂はハーボニー『配 合錠である可能性が極めて高いものと推定された.

2. ハーボニー配合錠あるいはソバルディ ${ }^{\circledR}$ 錠 $400 \mathrm{mg}$ とは異なる検体（検体 1, 2B 及び 5）

2-1. 検体 1 及び 5 検体 1 及び 5 は黄色の錠 剂であり，粉砕時の色は黄色粉末であった，正規品 であるハーボニー®配合錠（橙色）やソバルディ®錠 $400 \mathrm{mg}$ （黄色）の粉砕時は白色粉末であること, また外観や形状等から，これら 2 検体は，正規品で 


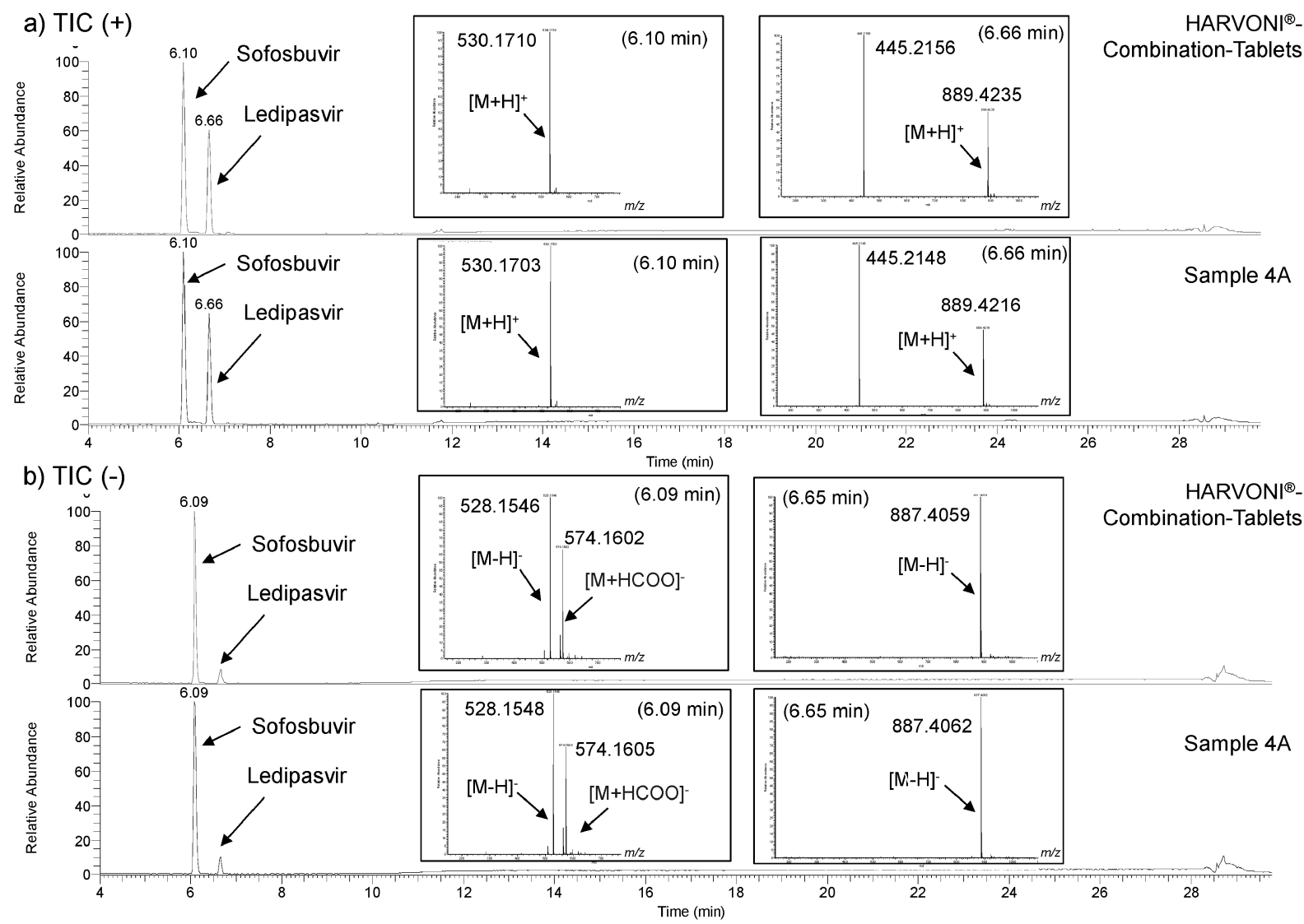

c) PDA $(262 \mathrm{~nm})$

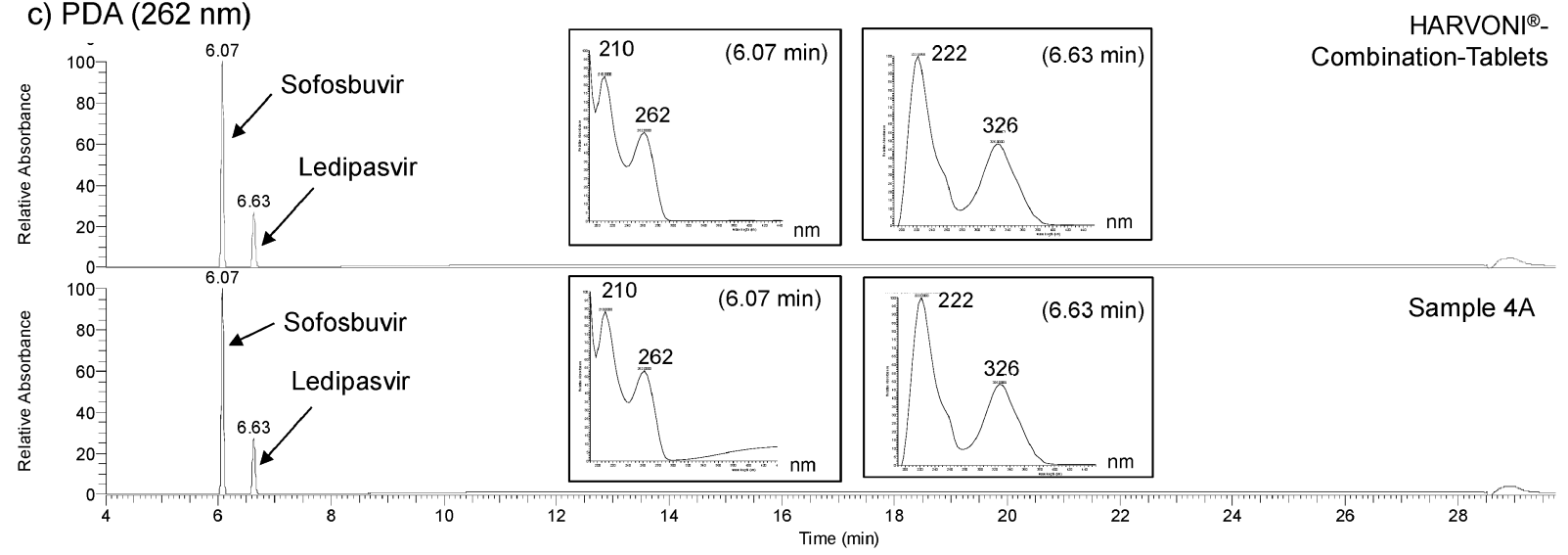

Fig. 3. LC-PDA-MS Analysis of HARVONI ${ }^{\circledR}$ Combination Tablets and Sample 4A

あるハーボニー『配合錠やソバルディ錠とは異なる ものであった（Tables 1 and 2). GC-MS 分析を 行った結果，検体 1 及び 5 から，ニコチンアミド (ナイアシン),$\alpha-, \beta-, \gamma$-トコフェロールが検出され た [Figs. 1(b) and 4(a), Supplementary material Fig. S-2]. 次に, LC-PDA-MS 分析を行った結果, 検体 1 及び 5 から，チアミン (Vitamin $\mathrm{B}_{1}$ ), ニコ チンアミド (ナイアシン), ピリドキシン（Vita$\left.\min \mathrm{B}_{6}\right)$ ，パントテン酸，リボフラビン（Vitamin
$\mathrm{B}_{2}$ ）が検出された [Figs. 1(b) and 4(b)，Supplementary material Fig. S-3 (a)]。 また, 両検体の TIC クロマトグラム（Pos/ Neg）及び PDA クロマ トグラムは類似していた [TIC（Pos）：Fig. 4(b)， Supplementary material Fig. S-3 (a)]。なお，各成分 は，標品との直接比較により，保持時間，精密質 量, マススペクトルの一致をもって同定した.

さらに，国内メーカーX 社より，自社のビタミ ン配合サプリメントが，検体 1 及び 5 の錠剤と外見 
a) $\mathrm{TIC}$

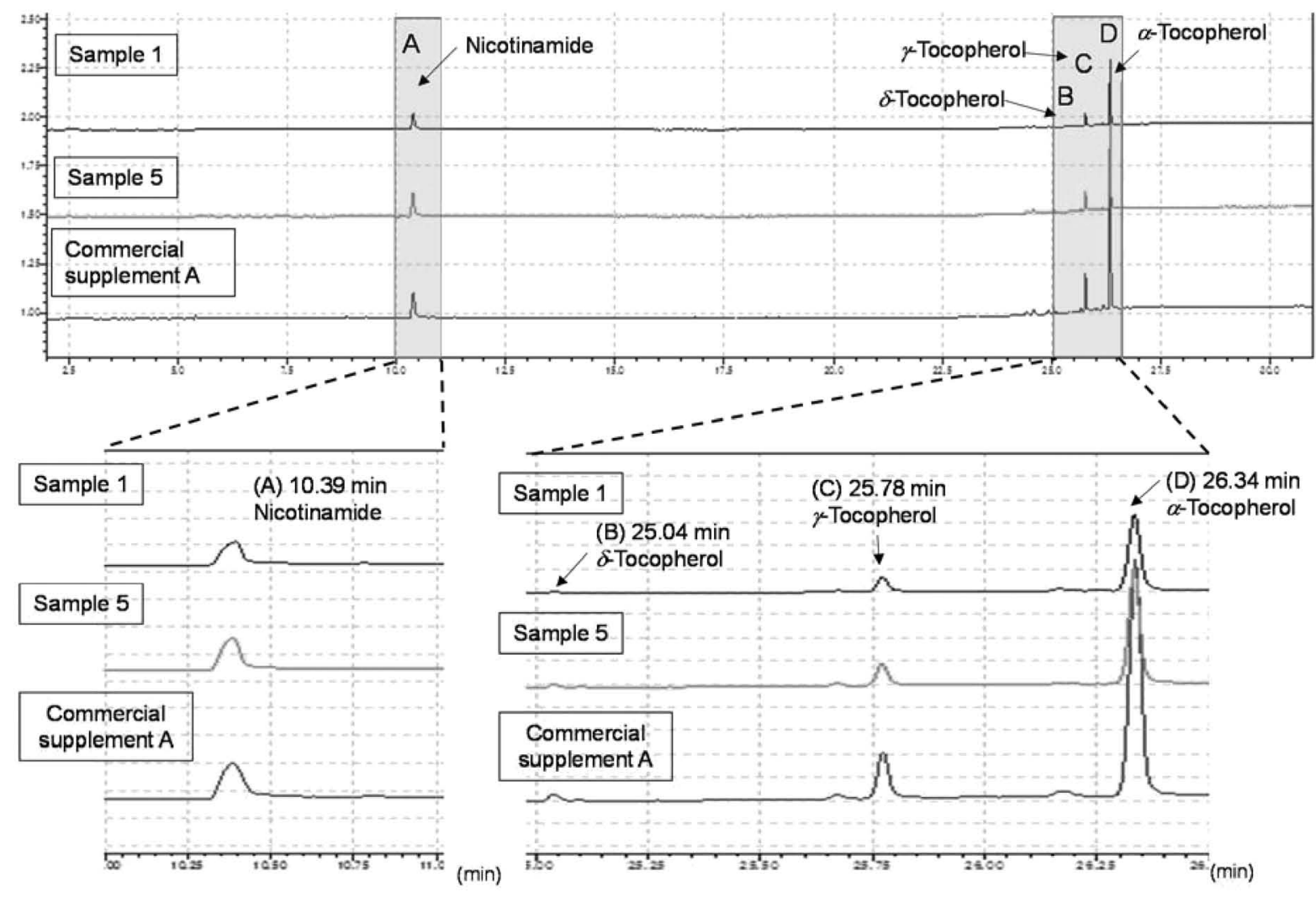

b) $\mathrm{TIC}(+)$

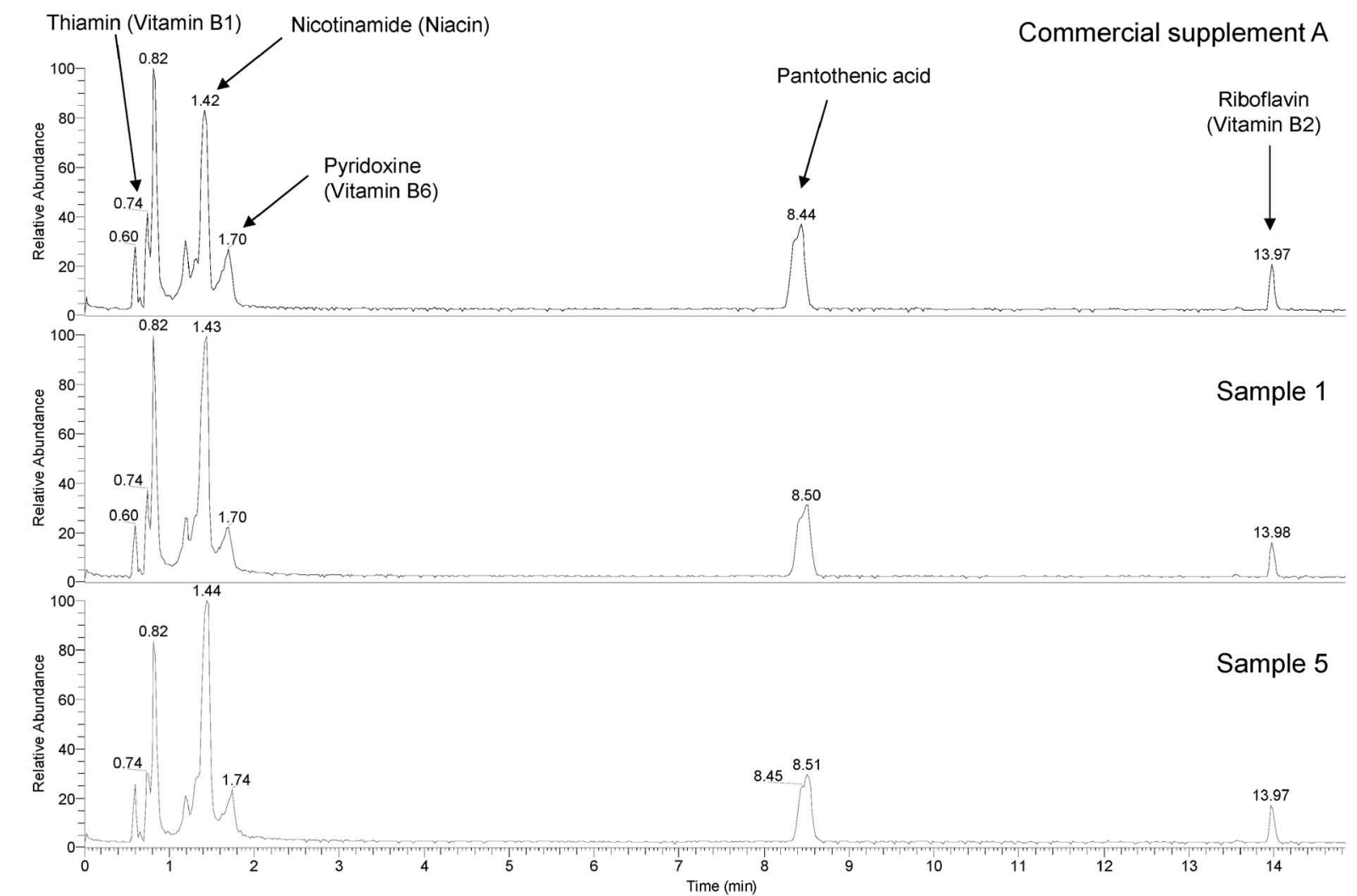

Commercial supplement $A$

Fig. 4. Total Ion Chromatograms of GC-MS (a) and LC-MS (Pos, b) of Commercial Supplement A, Samples 1 and 5 
上酷似しているとの申し出があり，該当する錠剤の 提供を受け，その形状，サイズ，色味などを比較し たところ，確かに酷似していた（Tables 1 and 2). また，GC-MS 及び LC-MS 分析において，X 社製 のビタミン配合サプリメントの成分プロファイルが 検体 1 及び 5 の錠剤に由来するものと類似していた [Figs. 4(a) and (b), Supplementary material Figs. S-3 (a) and (b)]．添加物，不純物プロファイル，等 の同等性は検証していないため, 確定的な結論を出 すことは難しいが，以上の分析結果及び各検体の外 観，サイズ，粉末の性状等から判断する限り，検体 1 及び 5 は， $\mathrm{X}$ 社製のビタミン配合サプリメントで ある可能性が極めて高いものと推定された。

\section{2-2. 検体 2B 検体 2B は紫色の錠剂であ} り，粉砕時の色は茶色粉末であった．正規品である ハーボニー配合錠（橙色）やソバルディ錠 400 $\mathrm{mg}$ （黄色）の粉砕時は白色粉末であること，また 外観や形状等から，本検体は，正規品であるハーボ ニー『配合錠やソバルディ®錠とは異なるものであっ た（Tables 1 and 2)。また，粉砕時に生薬あるいは ハーブ特有のにおいを発したことから，植物粉末な ぞが配合されている可能性が考えられたため，顕微 鏡による観察（鏡検）を行つた。しかし，植物の細 胞, 組織片, 器官, 等は観察されなかったことか ら, 検体 2B は植物由来のエキス剂の可能性が考え られた (data not shown).

GC-MS 分析を行った結果，検体 $2 \mathrm{~B}$ から，工 フェドリン，プソイドエフェドリン(マオウ成分), ケイヒ酸（ケイヒ，マオウなどの成分），[6]-ショ ウガオール（カンキョウなどの成分），[6]-ギンゲ ロール (ショウキョウ, カンキョウなどの成分), シザンドリン，ゴミシン A (ゴミシ成分)，アサリ ニン (サイシン成分), 以上 8 種類の生薬成分が検 出された [Figs. 1(c) and 5]. 次に, LC-PDA-MS 分析を行った結果，エフェドリン，プソイドエフェ ドリン (マオウ成分)，アルビフロリン，ペオニフ ロリン（シャクヤク成分），リクイリチン，グリチ ルリチン (カンゾウ成分), シザンドリン, ゴミシ ン A (ゴミシ成分)，アサリニン (サイシン成分), [6]-ショウガオール (カンキョウなどの成分), 以 上 10 種類の生薬成分が検出された [Figs. 1 (c) and 6, Supplementary material Figs. S-4 and 5).なお, 各成分は，標品との直接比較により，保持時間，精
密質量，マススペクトルの一致をもって同定した.

初期に行った GC-MS 及び LC-MS 分析による成 分プロファイル上で，まず，シャクヤク，カンゾ ウ，マオウ及びケイヒなどに特徵的な成分が検出さ れたことから，これらを配合生薬とする漢方処方と して葛根湯，小青竜湯，葛根湯加川芦辛夷，小青竜 湯合麻杏甘石湯，五積散などが候補に挙がった。こ れらの情報に加えて，錠剤の形状，サイズ，色味な ぞを勘案して国内医薬品製造メーカー等への聞き取 り調査及びインターネット検索を繰り返し，最終的 に国内メーカー A 社の葛根湯エキス錠剤あるいは 小青竜湯エキス錠剤に絞り込んだ。そこで，A 社 より葛根湯エキス錠剂及び小青竜湯エキス錠剤の提 供を受け，錠剂の形状，サイズ，色味を観察したと ころ，これらは酷似していた (Tables 1 and 2)。し かし，検体 2B 及び小青竜湯エキス錠剤は同程度の 重量であったが，葛根湯エキス錠剤の重量は $20 \mathrm{mg}$ 程度軽かった（Tables 1 and 2)。また，GC-MS 及 び LC-MS 分析において，A 社製の小青竜湯エキス 錠剂の成分プロファイルが検体 2B の錠剂に由来す るものと高度に一致した（Figs. 5 and 6, Supplementary material Figs. S-4 and 5)。一方，葛根湯 エキス錠剤の成分プロファイルとは明らかに異なっ ていた (Figs. 5 and 6, Supplementary material Figs. S-4 and 5). さらに, この分析過程で，検体 $2 \mathrm{~B}$ か ら，葛根湯には配合されず，小青竜湯に配合される 生薬であったゴミシの成分（シザンドリン，ゴミシ ン A), サイシンの成分（アサリニン）及びカン キョウの成分（[6]-ショウガオール）を検出した (Figs 5 and 6, Supplementary material Figs. S-4 and $5)$.

添加物，不純物プロファイル，製剤学的特性，等 の同等性は検証していないため, 確定的な結論を出 すことは難しいが，以上の分析結果及び各検体の外 観，サイズ，粉末の性状等から判断する限り，検体 2B の錠剂は， $\mathrm{A}$ 社製の小青竜湯エキス錠剤である 可能性が極めて高いものと推定された.

以上の結果から，本事案の偽造品 5 製品・計 7 検 体より検出された化合物及び分析結果より類推され る製品を Table 3 にまとめた. 


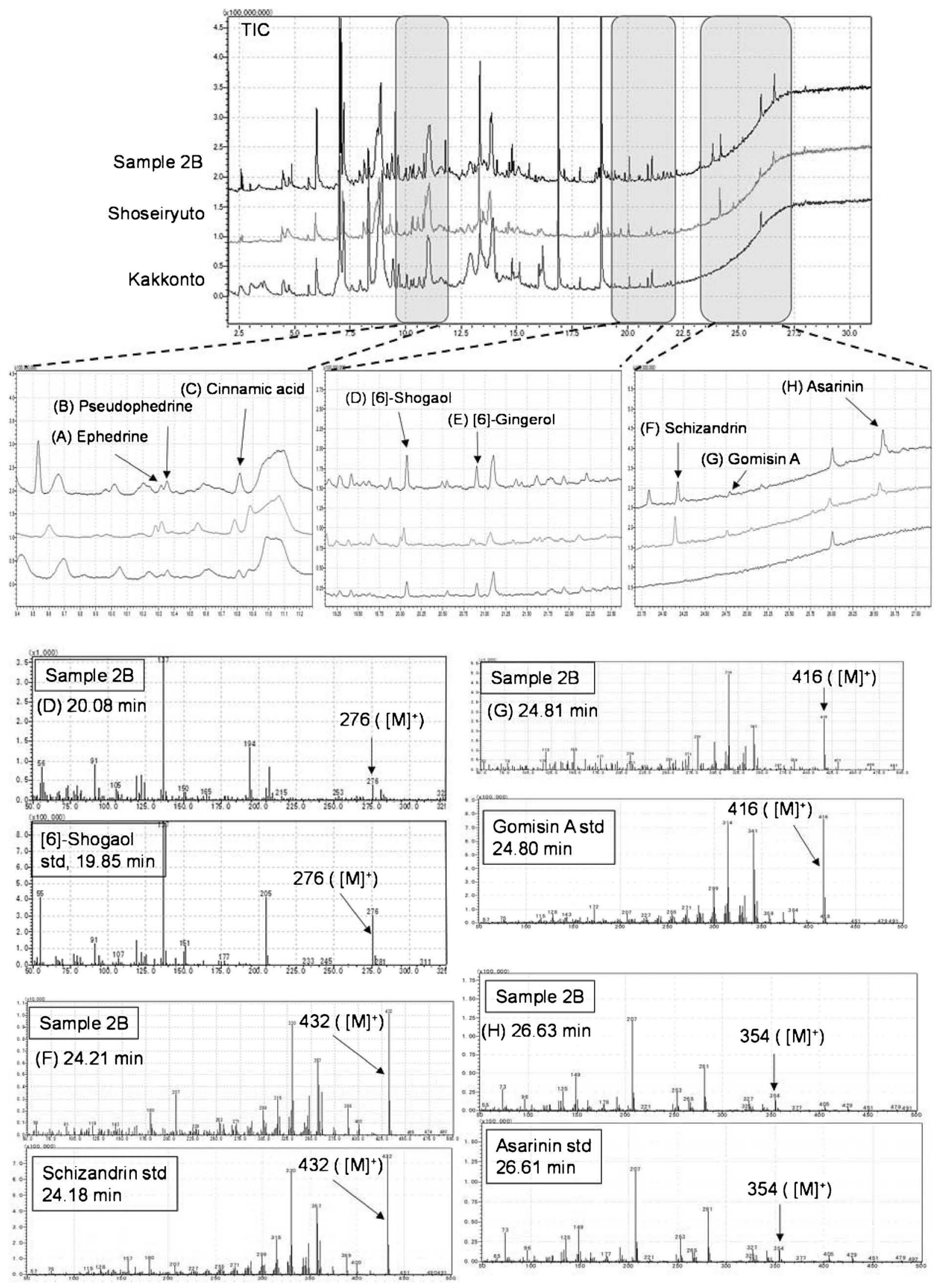

Fig. 5. GC-MS Analysis of Sample 2B, Kampo Extract Products of Kakkonto and Shoseiryuto 
a) TIC (Pos)

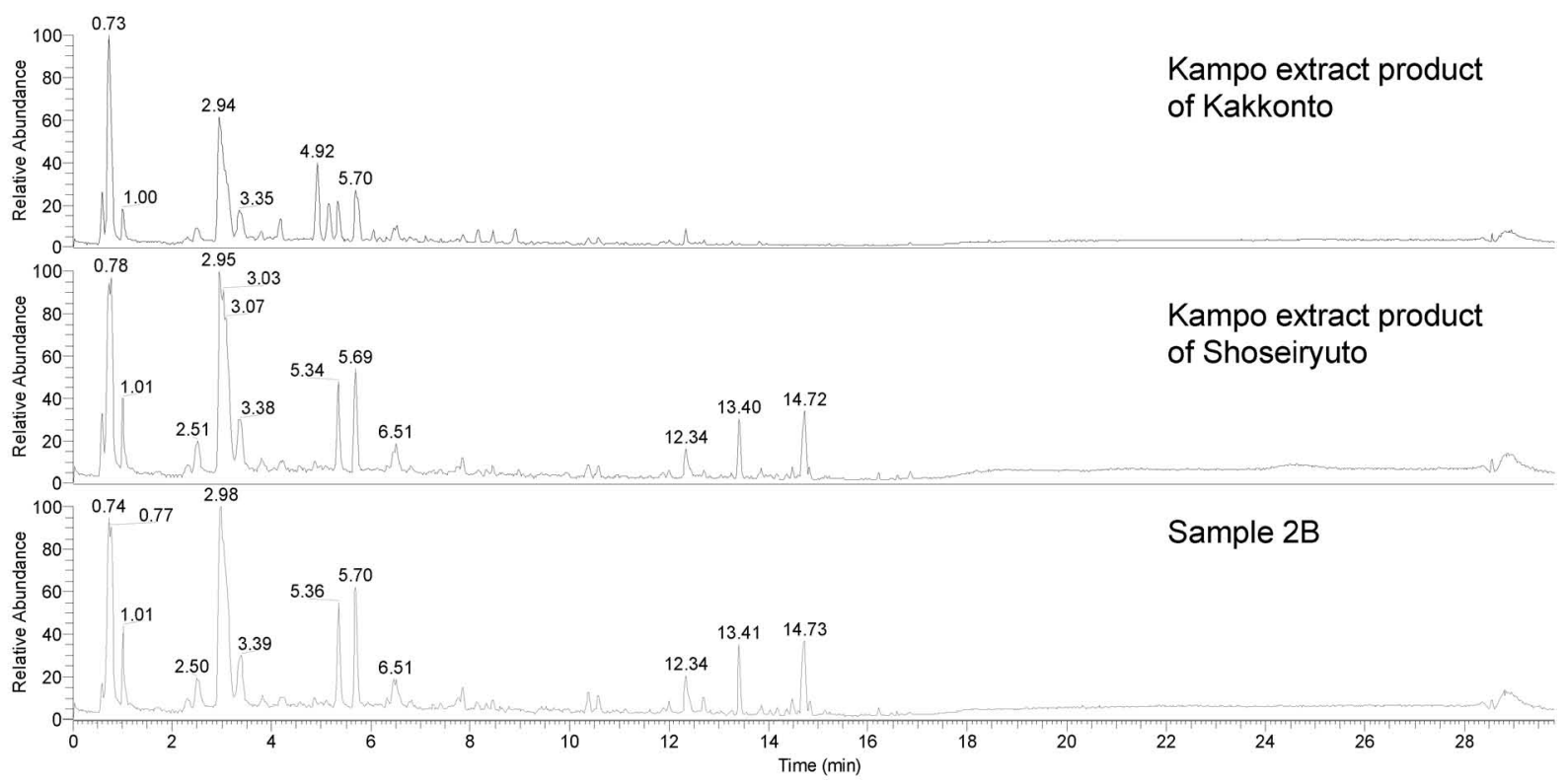

b) TIC (Pos), From 0 to $15 \mathrm{~min}$

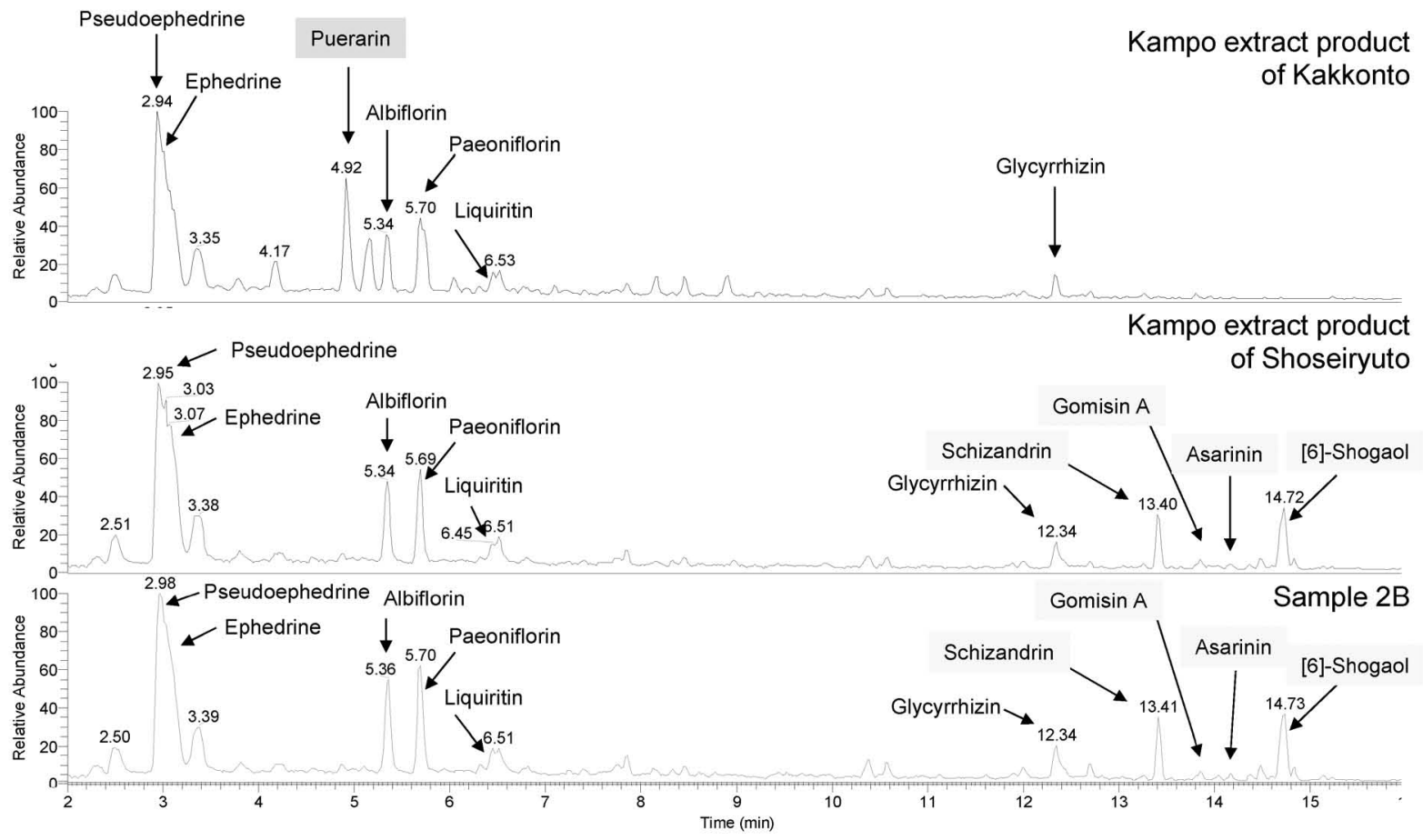

Fig. 6. LC-MS Chromatograms of Sample 2B, Kampo Extract Products of Kakkonto and Shoseiryuto (Pos)

考

察

今回の偽造品は, 7 検体中 6 検体がハーボニー ${ }^{\circledR}$ 配合錠の正規品と明らかに形状の異なる製品で偽造 されていたため, 患者でも容易に判別できるケース であった。本偽造品の流通事案の特徵として，1)
国内での医薬品の錠剂やカプセル剂の製品形態はブ リスター (PTP) 包装シートが主流であるが，ハー

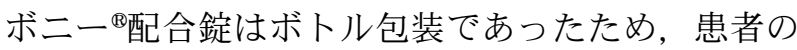
手に渡るまで偽造品とは認識されなかつた点，2) 前述の通り，チェーン薬局の経営会社が，製造販売 業者の正規取引以外の複数の卸売販売業者から本剂 
Table 3. Detected Compounds in Each Sample and the Estimated Products from the Analysis Results

\begin{tabular}{|c|c|c|c|}
\hline Sample & $\begin{array}{c}\text { Appearance form/ } \\
\text { Form and color after crushing }\end{array}$ & Detected compounds & Estimated product \\
\hline Sample 1 & $\begin{array}{l}\text { Yellow oblong tablet/ } \\
\text { Yellow powder }\end{array}$ & $\begin{array}{l}\text { Vitamins [Thiamin }\left(\mathrm{VB}_{1}\right) \text {, Riboflavine }\left(\mathrm{VB}_{2}\right) \text {, Pyridoxine } \\
\left(\mathrm{VB}_{6}\right) \text {, Nimotinamide, Pantohenic acid, } \alpha-, \beta, \gamma \text {-Tocopherol } \\
(\mathrm{VE})]\end{array}$ & Commercial supplement A \\
\hline Sample $2 \mathrm{~A}$ & $\begin{array}{l}\text { Yellow oblong tablet/ } \\
\text { White powder }\end{array}$ & Sofosbuvir & SOVALDI ${ }^{\circledR}$ Tablets $400 \mathrm{mg}$ \\
\hline Sample 2B & $\begin{array}{l}\text { Violet round tablet/ } \\
\text { Brown powder } \\
\text { (Characteristic odor like } \\
\text { crude drugs or herbs) }\end{array}$ & $\begin{array}{l}\text { Ephedrine, Pseudophedrine (contents of Ephedra Herb) } \\
\text { Albiflorin, Paeoniflorin (contents of Peony Root) } \\
\text { Liquiritin, Glycyrrhizin (contents of Glycyrrhiza) } \\
\text { Schizandrin, Gomisin A (contents of Schisandra Fruit) } \\
\text { Asarinin (contents of Asiasarum Root) } \\
\text { [6]-Shogaol (contents of Processed Ginger etc.) } \\
\text { [6]-Gingerol (contents of Processed Ginger, Ginger etc.) } \\
\text { Cinnamic acid (contents of Cinnamon Bark, Ephedra Herb } \\
\text { etc.) }\end{array}$ & $\begin{array}{l}\text { Kampo extract product of } \\
\text { Shoseiryuto }\end{array}$ \\
\hline Sample 3 & $\begin{array}{l}\text { Yellow oblong tablet/ } \\
\text { White powder }\end{array}$ & Sofosbuvir & SOVALDI ${ }^{\circledR}$ Tablets $400 \mathrm{mg}$ \\
\hline Sample 4A & $\begin{array}{l}\text { Orange diamond tablet/ } \\
\text { White powder }\end{array}$ & Sofosbuvir, Ledipasvir & $\begin{array}{l}\text { HARVONI }{ }^{\circledR} \text { Combination } \\
\text { Tablets }\end{array}$ \\
\hline Sample 4B & $\begin{array}{l}\text { Yellow oblong tablet/ } \\
\text { White powder }\end{array}$ & Sofosbuvir & SOVALDI ${ }^{\circledR}$ Tablets $400 \mathrm{mg}$ \\
\hline Sample 5 & $\begin{array}{l}\text { Yellow oblong tablet/ } \\
\text { Yellow powder }\end{array}$ & $\begin{array}{l}\text { Vitamins [Thiamin }\left(\mathrm{VB}_{1}\right) \text {, Riboflavine }\left(\mathrm{VB}_{2}\right) \text {, Pyridoxine } \\
\left(\mathrm{VB}_{6}\right) \text {, Nimotinamide, Pantohenic acid, } \alpha-, \beta, \gamma \text {-Tocopherol } \\
(\mathrm{VE})]\end{array}$ & Commercial supplement A \\
\hline
\end{tabular}

\section{を入手していた点, ${ }^{8-12)} 3$ 3) 本剤は極めて高額な医薬} 品である点が挙げられる。一方，本研究結果から， 偽造された各錠剂自体は海外の製品ではなく，国内 で流通又は製造された製品である可能性が高いこと が推定された，なお，本結果については，平成 29 年 2 月 1 日付の厚生労働省報道発表資料：C 型肝炎 治療薬「ハーボニー惧合錠」の偽造品について （第4 報）として報告されている. ${ }^{12)}$

さらに，本事案を受けて，製造販売会社であるギ リアド社は，「ハーボニー『配合錠」をボトル包装か ら視認性の高いブリスター（PTP）包装に平成 29 年 3 月より変更した。 また, 厚生労働省は, 医療用 医薬品の適正な流通を確保するため, 改めて医薬品 卸売販売業者や薬局に記録，管理の徹底を注意喚起 する通知及び監視指導の強化を求める通知を平成

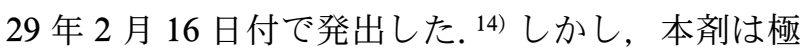
めて高額な医薬品であるため, 既存の強壮用や瘦身 用偽造品と同様に，外観も似せた偽造品が新たに流 通する可能性も危惧され, 今後も引き続き注意が必 要である.

\section{結 論}

本研究では，C型肝炎治療薬「ハーボニー ${ }^{\circledR}$ 配合 錠」の偽造品 5 製品・計 7 検体について分析を行つ た。 その結果, 3 検体からはソホスブビルが検出さ れ，1 検体からはソホスブビル及びレジパスビルが 検出されたことから，それぞれソバルディ錠 400 $\mathrm{mg}$ ，ハーボニー『配合錠の正規品である可能性が高 いものと推定された。また，2検体からは各種ビタ ミン類が検出され, 国内流通のサプリメントの可能 性が高いものと推定された。さらに，1検体からは 複数の生薬成分が検出され, 国内流通の鼻炎, 感冒 などに使用する漢方製剂（小青竜湯エキス錠剤）の 可能性が高いものと推定された.

謝辞本研究は, 厚生労働科学研究費補助金並 びに厚生労働省医薬品審査等業務庁費で行われたも のであり, 関係各位に深謝致します。また, ハーボ ニー『配合錠及びソバルディ『錠 $400 \mathrm{mg}$ の正規品及 び標準品をご提供下さったギリアド社，また，ビタ ミン配合サプリメント，葛根湯エキス錠剤及び小青 
竜湯エキス錠剂をご提供下さつた関係各社に感謝致 します。

\section{利益相反＼cjkstart開示すべき利益相反はない.}

\section{Supplementary materials この論文のオンライ ンに Supplementary materials（電子付録）を含ん でいます.}

\section{REFERENCES}

1) Ministry of Health, Labour and Welfare, 〈 http: / / www.mhlw.go.jp / kinkyu / diet / musyounin.html $\rangle$, cited 3 April, 2017.

2) Ministry of Health, Labour and Welfare, Press release, 31 March, 2017. Results of the "Purchase Survey of Internet Sales Products" in FY2014 are announced, Drug ingredients were detected in half or more so-called dietary supplements: 〈http://www.mhlw.go.jp/file/04Houdouhappyou-11126000-Iyakushokuhinkyo ku-Kanshishidoumayakutaisakuka/170331_press. pdf $\rangle$, cited 3 April, 2017.

3) Ministry of Health, Labour and Welfare, Press release, 23 February, 2017. Alert for dietary supplements containing hidden drug ingredients: 〈http://www.mhlw.go.jp / file / 04Houdouhappyou-11126000-Iyakushokuhinkyo ku-Kanshishidoumayakutaisakuka / 170223 fukuoka-press_1.pdf $\rangle$, cited 3 April, 2017.

4) Uchiyama N., Saisho K., Kikura-Hanajiri R., Haishima Y., Goda Y., Chem. Pharm. Bull., 56, 1331-1334 (2008).

5) Demizu Y., Wakana D., Kamakura H., Kurihara M., Okuda H., Goda Y., Chem. Pharm. Bull., 59, 1314-1316 (2011).

6) Hasegawa T., Saijo M., Ishii T., Nagata T., Haishima Y., Kawahara N., Goda Y., J. Food Hyg. Soc. Jpn., 49, 311-315 (2008) .

7) Kumasaka K., Kawahara N., Doi K., Kojima T., Goda Y., Chem. Pharm. Bull., 56, 227230 (2008).

8) Ministry of Health, Labour and Welfare, Press release, 17 January, 2017. "Iyakuhin no tekiseina ryutsu no kakuho nitsuite.”: 〈http:// www.mhlw.go.jp / file / 04-Houdouhappyou11126000-Iyakushokuhinkyoku-Kanshishidou mayakutaisakuka/170117_press_1.pdf $\rangle$, cited
23 January, 2017.

9) Ministry of Health, Labour and Welfare, Press release, 17 January, 2017. Alert for counterfeit hepatitis C therapeutic drug, "Harvoni Combination Tablets.": 〈http:// www.mhlw.go.jp / stf / houdou / 0000148807. html $\rangle$, cited 23 January, 2017.

10) Ministry of Health, Labour and Welfare, Press release, 23 January, 2017. Alert for counterfeit hepatitis C therapeutic drug, "Harvoni Combination Tablets" (The 2nd report ) : 〈http: // www.mhlw.go.jp / file / 04Houdouhappyou-11126000-Iyakushokuhinkyo ku-Kanshishidoumayakutaisakuka/0000149368. pdf $\rangle$, cited 27 January, 2017.

11) Ministry of Health, Labour and Welfare, Press release, 25 January, 2017. Alert for counterfeit hepatitis C therapeutic drug, "Harvoni Combination Tablets" (The 3rd report ) : 〈http: // www.mhlw.go.jp / file / 04Houdouhappyou-11121000-Iyakushokuhinkyo ku-Soumuka/0000149762.pdf $\rangle$, cited 27 January, 2017.

12) Ministry of Health, Labour and Welfare, Press release, 1 February, 2017. Alert for counterfeit hepatitis C therapeutic drug, "Harvoni Combination Tablets" (The 4th report ): 〈http: // www.mhlw.go.jp / file / 04Houdouhappyou-11126000-Iyakushokuhinkyo ku-Kanshishidoumayakutaisakuka/0000150190. pdf $\rangle$, cited 1 February, 2017.

13) Swiss Agency for Therapeutic Products: Swissmedic, Communications regarding the safety of medicines / Announcements, 4 March, 2016. "Hepatitis medicines: Warning concerning Harvoni ${ }^{\circledR}$ packs with counterfeit contents.": 〈 https: / / www.swissmedic.ch / aktuell $/ 00673 / 03287 /$ index.html?lang $=\mathrm{en}\rangle$, cited 7 May, 2017.

14) Ministry of Health, Labour and Welfare, Press release, 16 February, 2017. Proper distribution of pharmaceutical products for medical use to be fully enforced: 〈http://www.mhlw. go.jp / file / 04-Houdouhappyou-11126000Iyakushokuhinkyoku-Kanshishidoumayakutai sakuka/press_170216.pdf $\rangle$, cited 16 February, 2017. 